\title{
AKTIVITAS PENGHAMBATAN XANTHINE OXIDASE EKSTRAK ETANOL DAN AIR DARI HERBA SURUHAN (Peperomia pellucida L.)
}

\author{
Yunahara Farida $^{1,2}$, Rifaldi Agustian Firmansyah ${ }^{1}$ \\ ${ }^{1}$ Fakultas Farmasi Universitas Pancasila, Jakarta \\ ${ }^{2}$ Program Magister Ilmu Kefarmasian Universitas Pancasila, Jakarta \\ Email: yunahara_farida@yahoo.com
}

\begin{abstract}
ABSTRAK
Xanthine oxidase adalah enzim yang bekerja mengoksidasi hipoxanthine menjadi xanthine dan selanjutnya membentuk asam urat di dalam tubuh. Terjadinya peningkatan kadar asam urat didalam tubuh yang melebihi batas normal disebabkan mengkonsumsi makanan yang banyak mengandung purin dan kurangnya kemampuan ginjal dalam mengekskresikan asam urat. Herba suruhan (Peperomia pellucida L.) merupakan tanaman yang memiliki aktivitas dalam menghambat xanthine oxidase. Tujuan dari penelitian ini adalah menentukan daya hambat xanthine oxidase $\left(\mathrm{IC}_{50}\right)$ dari ekstrak etanol dan air. Hasil uji menunjukkan bahwa ekstrak kental herba suruhan dalam pelarut etanol dan pelarut air memiliki kadar flavonoid total sebesar 4,23\% dan $\mathrm{IC}_{50}$ 40,79 bpj dan Ekstrak kental herba suruhan dalam pelarut air memiliki kadar flavonoid sebesar 1,43\% dan $\mathrm{IC}_{50}$ 43,11 bpj. Ekstrak etanol dan air herba suruhan memiliki penghambatan terhadap xanthine oxidase.
\end{abstract}

Kata Kunci: herba suruhan, xanthine oxidase, flavonoid total, $\mathrm{IC}_{50}$

\begin{abstract}
Xanthine oxidase is an enzyme that oxidizes hypoxanthine into xanthine and then forming uric acid in the body, the increased levels of uric acid in the body that exceeds normal limits is caused by consuming foods that contain purine and the lack of kidneys ability to excrete uric acid. Suruhan herb (Peperomia pellucida L.) is a plant that has an activity for inhibiting xanthine oxidase. The purpose of this study is to determine the inhibition of xanthine oxidase $\left(\mathrm{IC}_{50}\right)$ of ethanol extract and water extract from suruhan herb. The results show that Suruhan herb extract in ethanol solvent has a total flavonoid content of $4.23 \%$ and $\mathrm{IC}_{50}$ of $40.79 \mathrm{ppm}$. Suruhan herb extract in water solvent has total flavonoid content of $1.43 \%$ and $\mathrm{IC}_{50}$ of $43.11 \mathrm{ppm}$. Ethanol and water extract of Suruhan herb have the inhibitory of xanthine oxidase.
\end{abstract}

Key words: Suruhan herb, xanthine oxidase, total flavonoids, $\mathrm{IC}_{50}$

\section{PENDAHULUAN}

Pada era modernisasi ini terdapat berbagai macam pengobatan untuk menyembuhkan berbagai penyakit yang ada di masyarakat dengan mencari pengobatan tradisional menggunakan tanaman. Salah satunya tanaman yang umum dimanfaatkan adalah tanaman tempuyangan air atau suruhan (Peperomia pellucida L.) yang berdasarkan penelitian menurunkan kadar asam urat darah atau sebagai antihiperurisemia Yunarto, N., 2013; Irma MT et.al.,2012). 
Hiperurisemia dapat disebabkan oleh produksi asam urat yang berlebih, dapat berkembang menjadi gout. Gout adalah jenis radang sendi/arthritis yang disebabkan oleh penumpukan kristal asam urat pada sendi.

Salah satu senyawa yang terkandung di dalam herba suruhan adalah senyawa flavonoid, dan hasil penelitian menunjukkan herba suruhan memiliki aktivitas dalam menghambat xanthine oxidase sehingga dapat menghambat pembentukan asam urat dalam tubuh (Yunarto, 2013; Cos et.al, 1998; Pacher et.al., 2006)).

Herba suruhan (Peperomia pellucida L.) adalah tanaman liar yang sangat mudah ditemukan di Indonesia. Herba suruhan tumbuh di tanah baik tanah yang gembur maupun tanah yang banyak mengandung air. Senyawa flavonoid yang umum dalam menghambat xanthine oxidase yaitu apigenin, luteolin, kamferol, kuersetin dan miresetin (Dalimartha S, 2000).

Penelitian terhadap herba suruhan ini yang sudah dilakukan antara lain sebagai antioksidan, antiinflamasi (Elisabeth, N.B., dkk, 2012), mempunyai efek antidibetes (Sri Hartati dkk,2010). Obat sintetik yang sering digunakan untuk mengobati penyakit asam urat adalah Allopurinol karena dapat menurunkan kadar asam urat dengan cara menghambat enzim xanthine oxidase. Dalam penggunaan obat ini tentu terdapat efek samping hipersensitivitas (Gunawan dkk, 2007).

Sebagai alternatif lain dalam menggunakan obat sintetik, maka telah dilakukan berbagai penelitian terhadap penghambatan enzim xanthine oxidase. Berdasarkan penelitian Nagao et al., senyawa flavonoid memiliki aktivitas penghambatan terbesar terhadap enzim xanthine oxidase dengan nilai penghambatan terbesar $0,44 \mu \mathrm{M}$. Dalam penelitian ini daya hambat yang ditunjukkan dengan nilai $\mathrm{IC}_{50}$ herba suruhan pada pelarut etanol dan air belum diketahui pada uji in vitro, sehingga dalam penelitian ini akan dilakukan pengujian aktivitas penghambatan enzim xanthine oxidase terhadap ekstrak air dan etanol.

\section{METODE PENELITIAN}

\section{Bahan:}

etanol 70\%, pereaksi Stiassny, substrat xantin (Sigma aldrich SA H9636-1G), xanthine oxidase dari bovine milk (Sigma aldrich SA X1875-5UN), allopurinol, dimetil sulfoksida (DMSO), asam klorida, natrium hidroksida, natrium sulfat anhidrat, metanol, asam sulfat, asam asetat anhidrat, natrium asetat, etil asetat, serbuk seng, serbuk magnesium, natrium karbonat, natrium klorida, gelatin, besi(III)klorida, alumunium klorida, kuersetin.

\section{Peralatan:}

$\begin{array}{llllll}\text { Pengaduk magnetik, Vakum rotavapor (Rotavapor IKA } & \text { RV } & 10\end{array}$ Control), spektrofotometer UV-Vis (Shimadzu UV-1800), kuvet kuarsa, pipet skala, mikro pipet, timbangan analitik, $\mathrm{pH}$ meter.

\section{Prosedur:}

\section{Pembuatan ekstrak:}

Sebanyak $\pm 300 \mathrm{~g}$ masing-masing serbuk herba suruhan (Peperomia pellucida L.) dimaserasi menggunakan etanol dan air. Selama 24-48 jam. Selanjutnya filtrat yang diperoleh dipekatkan dengan menggunakan rotavapor vakum pada suhu $40^{\circ} \mathrm{C}$ hingga diperoleh ekstrak kental, selanjutnya ekstrak kental ditimbang untuk mengetahui rendemen dan DER-native yang dihasilkan. 


\section{Identifikasi golongan senyawa kimia.}

Identifikasi golongan senyawa kimia yang terdapat dalam sampel menggunakan metode Fansworth (1996).

\section{Penetapan kadar flavonoid total (Farmakope Herbal Indonesia, 2008).}

Ditimbang tepat ekstrak yang setara dengan $200 \mathrm{mg}$ simplisia, masukkan ke dalam labu alas bulat, ditambahkan 1,0 mL larutan 0,5\% HMT, $20 \mathrm{~mL}$ aseton dan $2 \mathrm{~mL}$ larutan $25 \% \mathrm{HCl}$ dalam air, refluks selama 30 menit. Saring menggunakan kapas ke dalam labu ukur $100 \mathrm{~mL}$. Refluks kembali residu dengan $20 \mathrm{~mL}$ aseton selama 25 menit, saring dan campur filtrat ke dalam labu tentukur $100 \mathrm{~mL}$. Tambahkan aseton sampai tanda. $20 \mathrm{~mL}$ filtrat dimasukkan corong pisah, tambahkan $20 \mathrm{~mL}$ air dan diekstraksi 3 kali, tiap kali menggunakan $15 \mathrm{~mL}$ etil asetat. Masukan fase etil asetat dalam labu ukur $50 \mathrm{~mL}$ tambahkan etil asetat sampai tanda.

Masukkan $10 \mathrm{~mL}$ larutan fraksi etil asetat ke dalam labu ukur $25 \mathrm{~mL}$, tambahkan 1 $\mathrm{mL}$ larutan $2 \mathrm{~g}$ aluminium klorida dalam $100 \mathrm{~mL}$ larutan asam asetat glasial 5\% v/v dalam metanol sampai tanda. Hasil reaksi diukur menggunakan spektrofotometer pada panjang gelombang 426,5 nm. Perhitungan kadar menggunakan bahan standar kuersetin. Perhitungan flavonoid total menggunakan rumus

$$
\%=\quad \frac{\mathrm{Cp} A u-A b u \times}{A p ~ A b p} 1,25 \times \frac{100 \mathrm{ml} \times}{\text { berat sampel }(\mathrm{mg})} 100 \%
$$

\section{Uji aktivitas penghambat xanthine oxidase.}

Uji aktivitas penghambat xanthine oxidase menggunakan metode Owens yang dimodifikasi secara spektrofotometri UV-Vis Owen, P., 1999; Yumita dkk, 2013) dan digunakan allopurinol sebagai kontrol positif dan xanthine sebagai substrat. Larutan uji yang dihasilkan diukur aktivitas penghambatan xanthine oksidase nya. Larutan uji sebanyak $1 \mathrm{~mL}$ dari masing-masing konsentrasi 3,$125 ; 6,25 ; 12,5 ; 25 ;$ dan $50 \mu \mathrm{g} / \mathrm{mL}$, ditambahkan 2,9 mL larutan dapar fosfat $50 \mathrm{mM}(\mathrm{pH} \mathrm{7,5)}$ dan $2 \mathrm{~mL}$ larutan substrat (xantin 0,20 mM dalam dapar fosfat $\mathrm{pH} 7,5$ ). Setelah dilakukan pra inkubasi pada suhu $25^{\circ} \mathrm{C}$ selama 15 menit, reaksi dimulai dengan penambahan $0,1 \mathrm{~mL}$ larutan enzim $(0,3$ $\mathrm{U} / \mathrm{mL}$ dalam dapar fosfat $(\mathrm{pH} 7,5)$. Larutan campuran diinkubasikan pada suhu $25^{\circ} \mathrm{C}$ selama 30 menit. Reaksi dihentikan dengan penambahan $1 \mathrm{~mL} \mathrm{HCl} 1 \mathrm{~N}$ sehingga diperoleh asam urat dalam larutan yang di uji tersebut, kemudian asam urat tersebut diukur serapannya pada rentang panjang gelombang 283-295 $\mathrm{nm}$ menggunakan spektrofotometri UV-Vis. Larutan blangko disiapkan dengan cara yang sama. Satu unit xanthine oxidase didefinisikan sebagai jumlah enzim yang diperlukan untuk menghasilkan 1 mmol asam urat permenit pada suhu $25^{\circ} \mathrm{C}$. Alopurinol digunakan sebagai kontrol positif dengan konsentrasi 0,$25 ; 0,5 ; 0,75 ; 1,0$ dan $1,25 \mu \mathrm{g} / \mathrm{mL}$.

Aktivitas xanthine oxidase dinyatakan sebagai persen penghambatan xanthine oxidase yang dihitung menggunakan rumus :

$$
\% \text { penghambatan }=\frac{\mathrm{A}-\mathrm{B}}{\mathrm{A}} \times 100 \%
$$

Keterangan :

$\mathrm{A}=$ Perubahan serapan uji tanpa ekstrak (serapan blangko - serapan kontrol blangko).

$\mathrm{B}=$ Perubahan serapan uji dengan adanya ekstrak (serapansampel/pembanding serapan kontrol sampel/pembanding).

Nilai IC50 dihitung menggunakan persamaan regresi, yaitu persamaan $\mathrm{y}=\mathrm{a}+\mathrm{bx}$ dimana nilai $\mathrm{x}=$ konsentrasi dan $\mathrm{y}=\%$ inhibisi. Aktivitas penghambatan xanthine oxidase 
dinyatakan dengan Inhibition Concentration 50\% (IC50) yaitu konsentrasi yang dapat menghambat aktivitas enzim xanthine oxidase sebesar $50 \%$.

$\mathrm{Y}=50$, maka persamaan menjadi :

$50=a+b x$, maka

$$
x=\frac{50-a}{b}
$$

\section{HASIL DAN PEMBAHASAN}

Hasil penapisan fitokimia terhadap ekstrak etanol dan air herba suruhan dapat dilihat pada Tabel 1.

Tabel 1. Hasil Penapisan fitokimia terhadap ekstrak etanol dan ekstrak air herba suruhan

\begin{tabular}{|l|c|c|}
\hline Golongan Senyawa kimia & Ekstrak Etanol & Ekstrak Air \\
\hline Alkaloid & + & + \\
\hline Flavonoid & + & + \\
\hline Tanin & - & - \\
\hline Saponin & + & + \\
\hline Kuinon & + & + \\
\hline Kumarin & - & - \\
\hline Steroid/Triterpenoid & $+/-$ & $+/-$ \\
\hline Minyak Atsiri & - & - \\
\hline
\end{tabular}

Pada Tabel 1 dapat dilihat bahwa hasil identifikasi golongan kimia terhadap ekstrak etanol dan ekstrak air dan dalam bentuk serbuk halus mengandung metabolit sekunder golongan alkaloid, flavonoid, kuinon, kumarin, saponin dan steroid. Menurut Cos et.al.(1998), beberapa senyawa flavonoid dan alkaloid dapat menghambat kerja enzim xanthin oxidase sehingga dapat menghambat pembentukan asam urat dalam tubuh.

Pada penetapan kadar flavonoid total, digunakan kuersetin sebagai baku pembanding. Kuersetin akan bereaksi dengan alumunium klorida $\left(\mathrm{AlCl}_{3}\right)$ sehingga terjadi pergeseran panjang gelombang maksimum, maka perlu dilakukan penentuan panjang gelombang maksimum dengan melihat spektrum serapan. Diperoleh hasil panjang gelombang maksimum pada $426,5 \mathrm{~nm}$. Hasil penetapan kadar flavonoid total ekstrak etanol dan air herba suruhan diperoleh kadar flavonoid total dari ekstrak etanol sebesar 4,23\% dan ekstrak air sebesar 1,43\%. Hasil penetapan kadar tersebut menunjukkan bahwa ekstrak suruhan dalam pelarut air mempunyai kadar flavonoid total yang lebih kecil dibandingkan dengan ekstrak suruhan dalam pelarut etanol. hal ini mungkin disebabkan karena adanya golongan flavonoid di dalam ekstrak air yang tidak dapat terdeteksi dengan pereaksi $\mathrm{AlCl}_{3}$ secara spektrofotometri UV-Vis yang diakibatkan karena tidak semua komponen flavonoid pada herba suruhan yang terekstrasi dalam pelarut air, sehingga dapat menurunkan kadar flavonoid total didalam ekstrak air tersebut. Sedangkan kadar flavonoid total ekstrak etanol lebih besar dibandingkan ekstrak air, hal ini disebabkan semua komponen flavonoid pada herba suruhan terekstrasi sempurna dalam pelarut etanol.

Hasil uji aktivitas penghambatan xanthine oxidase dari ekstrak etanol dan air herba suruhan dan allopurinol sebagai kontrol positif seperti terlihat pada Tabel 2. 
Tabel 2. Hasil uji aktivitas penghambatan xanthine oxidase dari ekstrak herba suruhan dan allopurinol

\begin{tabular}{|c|c|c|c|}
\hline Sampel & $\begin{array}{c}\text { Konsentrasi } \\
(\mu \mathrm{g} / \mathrm{mL})\end{array}$ & Inhibisi (\%) & $\mathrm{IC}_{50}$ (bpj) \\
\hline \multirow{5}{*}{ Ekstrak Etanol } & 3,125 & 30,06 & \multirow{5}{*}{40,79} \\
\hline & 6,25 & 33,54 & \\
\hline & 12,5 & 40,88 & \\
\hline & 25 & 46,80 & \\
\hline & 50 & 51,77 & \\
\hline \multirow{5}{*}{ Ekstrak Air } & 3,125 & 33,20 & \multirow{5}{*}{43,11} \\
\hline & 6,25 & 33,61 & \\
\hline & 12,5 & 40,00 & \\
\hline & 25 & 44,22 & \\
\hline & 50 & 51,77 & \\
\hline \multirow{5}{*}{ Allopurinol } & 0,25 & 45,92 & \multirow{5}{*}{0,37} \\
\hline & 0,50 & 52,18 & \\
\hline & 0,75 & 61,90 & \\
\hline & 1,0 & 66,99 & \\
\hline & 1,25 & 68,03 & \\
\hline
\end{tabular}

Berdasarkan $\mathrm{IC}_{50}$ menunjukkan bahwa ekstrak etanol dan ekstrak air herba suruhan memiliki aktivitas penghambatan xanthine oxidase. Aktivitas penghambatn dari ekstrak etanol lebih baik dibandingkan dengan ekstrak air, hal ini mungkin disebabkan karena tidak seluruhnya komponen dalam flavonoid (flavon) pada herba suruhan terekstraksi oleh air dan terdapat senyawa flavon lainnya selain flavonoid yang tersari dalam pelarut etanol namun pada air tidak tersari sempurna. Hasil pengujian dari allopurinol menunjukkan bahwa ekstrak etanol dan ekstrak air dari herba suruhan masih jauh lebih rendah aktivitas penghambat xanthine oxidase nya.

\section{KESIMPULAN}

Berdasarkan penapisan fitokimia, herba suruhan mengandung golongan senyawa flavonoid, alkaloid, saponin, kuinon dan steroid.

Ekstrak etanol herba suruhan memiliki aktivitas penghambatan xanthin oxidase lebih baik ( $\mathrm{IC}_{50} 40,79 \mathrm{bpj}$ ) dibandingkan ekstrak air herba suruhan ( $\mathrm{IC}_{50} 43,11 \mathrm{bpj}$ ), tetapi lebih kecil dibandingkan dengan allopurinol (0,37 bpj).

Berdasarkan penetapan kadar flavonoid total dengan menggunakan $\mathrm{AlCl}_{3}$ menunjukkan bahwa ekstrak suruhan dalam pelarut etanol lebih besar $(4,23 \%)$ dibandingkan ekstrak suruhan dalam pelarut air (1,43\%).

\section{DAFTAR PUSTAKA}

1. Yunarto, N.., 2013. Efek Ekstrak Air dan Heksan Herba Suruhan Peperomia pellucida L. terhadap Penurunan Kadar Asam Urat Serum Darah Ayam Kampung Jantan. Media Litbangkes Vo.23 No.1 (Maret).Jakarta.

2. Irma M.Tarigan., Saiful B., Awaluddin S., 2012. Aktivitas Antihiperurisemia Ekstrak Etanol Herba Suruhan (Peperomia pellucida (L.) Kunth) Pada Mencit Jantan, J.of Pharm.and Pharmacol, Vol 1(1):37-43

3. Cos P., et.al., 1998. Structure Activity Relationship and Classification of Flavonoids as Inhibitors of Xanthine Oxidase and Superoxide Scavengers, J.Nat.Prod., 61:71-76 
4. Pacher P, Nivorozhkin A, Szabo C., 2006. Therapeutic Effects of Xanthine Oxydase Inhibitors: Renaissance Half a Century after the Discovery of Allopurinol. J. Pharmacol. Rev. Vol.59(1):87-114.

5. Dalimartha S. 2000. Atlas Tumbuhan Obat Indonesia. Jilid 4. Jakarta: Trubus Agriwidya, h.91-92

6. Elisabeth N.B., Adeanne C.W., Ivitny P., 2012. Uji efektivitas antiinflamasi infus herba suruhan (Peperomia pellucida L.) pada tikus putih (Rattus norvegicus. Jurnal Ilmiah Farmasi Vol 3 No.2

7. Sri Hartati H., R.P Andri Putranto, Hari Purnomo, Diding HP, 2010. Efek hipoglikemik ekstrak etanol herba suruhan (Peperomia pelucida L.) pada tikus diabetik yang diinduksi streptozotocin. J. Bahan Alam Indonesia Vol.7 No.3.

8. Gunawan,S.G., R.Setyabudi,FD., Nafrialdi \& Elysabeth, 2007. Farmakologi dan terapi, 2007. Edisi 5. Jakarta: Fakultas Kedokteran Universitas Indonesia.

9. Nagao A, Seki M, Kobayashi H., 1999. Inhibition of Xanthine Oxydase by Flavonoids. J. Biochem. Vol.63(10):1787-1790

10. Fansworth, Norman R. Biological and phytochemical screening of plants. Journal of Pharmaceutical Science, 1966; 55 : 226-276; 262,264

11. Departemen Kesehatan Republik Indonesia. Farmakope Herbal Indonesia. Edisi I. Jakarta: Direktorat Jenderal Pengawasan Obat dan Makanan; 2008

12. Owen P, Johns T., Xanthine oxidase inhibitory activity of northeastern North American plant remedies used for gout. J.of Ethnopharmacology 1999; 64:149-160

13. Yumita A, Suganda AG, Sukandar EY. Xanthine oxidase inhibitory activity of some indonesian medicinal plants and active fraction of selected plants. 2013; $5: 295$.

14. Harborne JB, 1996. Metode fitokimia penuntun cara modern menganalisis tumbuhan. Edisi 2. Diterjemahkan oleh Kosasih P, Iwang S. Bandung: Penerbit ITB; h. 6- 8,87,9799.

15. Pulak, M., Priya, A., Satya, V., Ethno-medicinal, Phytochemical and Pharmacological review of an amazing medicinal herb Peperomia pellucida (L.) HBK, Research Journal of Pharmaceutical, Biological and Chemical, 2011, Vol 2(4), 358-364. 